Bangl. J. Vet. Med. (2008). 6 (1): 53-58

\title{
HAEMOPROTOZOAN INFECTION IN DUCKS: PREVALENCE AND PATHOLOGY
}

\author{
A. R. Dey, N. Begum, Anisuzzaman, M. A. H. N. A. Khan ${ }^{1}$ and M. M. H. Mondal \\ Department of Parasitology, ${ }^{1}$ Department of Pathology, Faculty of Veterinary Science, Bangladesh Agricultural \\ University, Mymensingh-2202, Bangladesh
}

\begin{abstract}
The prevalence of haemoprotozoa in duck and pathological changes produced by these parasites were studied in different areas of Mymensingh district during July, 2007 to December, 2007. In this study $60 \%$ ducks were found to be infected with haemoprotozoa. Two species of haemoprotozoa were identified such as Leucocytozoon caulleryi and Leucocytozoon simondi. Prevalence of L. caulleryi $(54.67 \%)$ was significantly $(\mathrm{P}<0.01)$ higher than that of L. simondi $(5.33 \%)$ in ducks. The calculated odds ratio implied that ducks were 19.67 times more susceptible to $L$. caulleryi infection than $L$. simondi infection. Prevalence of haemoprotozoa was significantly $(\mathrm{P}<0.01)$ higher in male $(78.94 \%)$ than female ducks $(53.57 \%)$. Pathological lesions were observed in case of Leucocytozoon sp. infections. Grossly lungs were congested but other suspected organs such as liver, lungs, kidney and heart were apparently normal. Microscopically, comma shaped organisms were found in the hepatocyte of liver and alveolar epithelial cell of lungs accompanied with eosinophilic infiltration. Schizonts were also observed in the hepatocyte of liver and alveolar epithelial cell of lungs. The lungs alveoli were distended and ruptured in advanced stages. According to the result, it may be concluded that haemoprotozoan infection in duck is highly prevalent in Bangladesh and produces clinicopathological lesions in duck. So proper control measures should taken to reduce the prevalence of haemoprotozoa of duck in Bangladesh.
\end{abstract}

Key words: Haemoprotozoa, ducks, prevalence, pathology

\section{INTRODUCTION}

Bangladesh is a developing country where poultry industry is a rising sector. The duck population in Bangladesh is 39.08 millions (Anon, 2007). It plays an important role in rural economy. Local ducks are ubiquitous in the country and smallholder farmers keep them under a subsistent level of management (Islam et al., 2003). But duck rearing is hindered by various problems, of which parasitic infections is one of a major problem.

Many recent studies have focused on avian blood parasites as a model system for host-parasite interactions is an evolutionary and ecological context (Bensch et al., 2004; Hellgren et al., 2004 and Ricklefs et al., 2005). The prevalence of Leucocytozoon simondi is 9.2\% in ring-necked ducks (Aythya collaris) in Florida (Forrester et al., 2001) and $91.2 \%$ in Canada (Bennett et al., 1991). The pathogenicity of Leucocytozoon simondi has been studied in ducklings. This parasities produces inappetence, weakness listlessness, dyspnea, anaemia, leukocytosis and sometimes death within $24 \mathrm{hr}$. Splenomegaly and liver degeneration have encountered in Leucocytozoon simondi infection in duckling. Extensive tissue damage was noted in spleen and heart of ducks carrying megaloschizont of Leucocytozoon simondi (Springer, 1997). In North America, L. simondi were associated with heavy mortality of duck especially domestic duck (Shutler et al., 1999). By considering the above mentioned points, this research work was conducted, to detect different haemoprotozoa in duck along with their prevalence and pathological lesion produced by this haemoprotozoa.

\section{MATERIALS AND METHODS}

To study the prevalence of haemoprotozoa of ducks and the pathological changes produced by them, ducks were selected randomly and collected from different local market and from farmer's house of different villages of Mymensingh district. 


\section{Ante-mortem examination}

After collection of birds, age, sex, breed and body weight were recorded. Birds were examined carefully by parting of feathers against their natural direction and simultaneous close inspection to detect clinical signs if any and also to collect ectoparasites.

\section{Collection and staining of blood and identification of protozoa}

Blood samples were collected from the wing vein of ducks with the help of syringe and needle. The thin smear was made immediately after the collection of blood for identification of blood protozoa. The smear was then air dried, fixed with absolute acetone free methanol, stained with Giemsa's stain and then air dried (Cable, 1957). The slides were then examined under microscope in higher magnification $(40 \mathrm{X}, 100 \mathrm{X})$ for the detection of blood protozoa. Protozoa were identified according to the keys and descriptions given by Levine (1985), Springer (1997) and Soulsby (1982).

\section{Post-mortem examination}

After ante-mortem examination, birds were slaughtered and allowed to bleed completely and then post-mortem examination was performed as described by Fowler (1990). The skin over-lying the breast and fluff were carefully removed. Then the abdominal wall was incised along the midline, starting from cloaca up to the posterior margin of the keel bone by a scissors. The ribs were then cut just lateral to the keel bone and keel bone was separated. After the opening of thoracic and abdominal cavities, the internal organs such as lung, heart, liver, spleen, kidney and ovary was examined carefully to detect pathological changes.

\section{Histopathological examination}

During necropsy suspected tissues were collected and fixed in $10 \%$ buffered neutral formalin for histopathological studies. Formalin fixed tissue samples were processed, embedded, blocked and sectioned and stained with Haematoxylin and Eosin stain following standard method (Luna, 1968).

\section{RESULTS AND DISCUSSION}

\section{Prevalence of parasites in duck}

In this study, 75 ducks were necropsied whereas 45 (60\%) ducks were affected with haemoprotozoa. Ducks were found to be infected with Leucocytozoon simondi and Leucocytozoon caulleryi. Prevalence of L. caulleryi $(54.67 \%)$ was significantly $(\mathrm{P}<0.01)$ higher than that of $L$. simondi $(5.33 \%)$ in ducks. The calculated odds ratio implied that ducks were 19.67 times more susceptible to L. caulleryi infection than $L$. simondi infection (Table 1). Similar studies were also conducted by other scientists in different countries. Benenett et al. (1975) reported $30 \%$ haemoprotozoan infection in ducks in Nova Scotia and Prince Edward Island. Thul et al. (1980) found L. simondi infection in 20\% ducks in Atlantic Flyway. Williams et al. (1977) recorded higher percentage (86\%) of $L$. simondi in ducks in Alberta and the Mackenzia Delta. This variation among the present and previous studies may be due to the differences in geographic niches, breeds of ducks, management factors and method of study. In this study only backyard ducks were included and their management is relatively poor than any other system.

Table 1. Haemoprotozoa of duck in Bangladesh

\begin{tabular}{|lllll|}
\hline Name of protozoa & Location & Prevalence (\%) & Parasitemia & OR \\
\hline L. simondi & Lymphocyte & $4(5.33)$ & $1-2 \%$ & 19.67 \\
L. caulleryi & Lymphocyte & $41(54.67)$ & $6-22 \%$ & \\
\hline Total $(\mathrm{n}=75)$ & - & $45(60)$ & - & - \\
\hline
\end{tabular}

$\mathrm{OR}=$ Odds ratio. 
Prevalence of haemprotozoa was significantly $(\mathrm{P}<0.05)$ higher in male $(78.94 \%)$ then in female $(53.47 \%)$. The calculated odds ratio showed that male ducks were 3.25 times more susceptible then the female ducks (Table 2). This result could not be compared due to paucity of relevant literatures. The exact cause of higher parasitic infection in male can not be explained. However, the female sex hormones are associated with lower mean parasitic burden (Ackert and Dewhirst, 1950; Todd and Hollingsworth, 1951). This phenomenon may have role in the lower prevalence of haemoprotozoan infection in female.

Table 2. Sex-wise prevalence of haemoprotozoa in duck

\begin{tabular}{|lllll|}
\hline Parameter & Name of protozoa & Prevalence $(\%)$ & P-value & OR \\
\hline Male & L. simondi & $4(21.05)$ & 0.685 & \\
$(\mathrm{n}=19)$ & L. caulleryi & $11(57.89)$ & 0.021 & Male vs \\
& Total & $15(78.94)$ & 0.0002 & female 3.25 \\
Female & L. simondi & $0(0)$ & - & \\
$(\mathrm{n}=56)$ & L. caulleryi & $30(53.57)$ & 0.001 & \\
& Total & $30(53.57)$ & 0.0002 & \\
& & & & \\
\hline
\end{tabular}

$\mathrm{OR}=$ Odds ratio

In this study, both $L$. simondi and L. caulleryi were found in lymphocytes. Incase of $L$. simondi infection, the gametocytes were found in leucocyte and in Giemsa's stain these were more or less elongated measuring upto 14 to $22 \mu$ long in their host cells. In some cases this size extended upto 45 to $55 \mu$. The nucleus of the host cell was seen forming a very long, thin, dark band in one side of the cell. Pale cytoplasmic horns were seen in either sides, extending out beyond the parasite and the nucleus (Fig. 1). The gametocyte found in leucocyte specially lymphocyte. These descriptions were in conformity to the keys and description given by Levine (1985).

In $L$. caulleryi infection, the gametocyte, which was identified from the leucocyte were round and measuring 15.5 by $15.0 \mu$. The nucleus of the host cell formed a narrow dark violet coloured band extending about a third of the way around the parasite. Infected cells were some what larger (Fig. 2). This description was almost similar to the descriptions of Levine (1985). In L. caulleryi infection about $6-22 \%$ cells were found to be infected whereas incase of $L$. simondi infection only $1-2 \%$ cells were infected. This result could not be compared due to lack of relevant literatures.

\section{Pathology produced by haemoprotozoa in duck}

Grossly, the lungs were congested (Fig. 3) but there were no other gross lesions in any organs. Microscopically, in lungs, there were lots of eosinophilic infiltration and blood vessels were congested. The congested area contains aberrant structure suggesting the presence of haemoprotozoa (Fig. 4). Few RBC displayed multiple parasitic inclusions. Comma shaped gamete of haemoprotozoa were seen in between the cord of hepatocytes in liver (Fig. 5). Schizont like structures were seen in the alveolar epithelium of the affected lung accompanied with neutrophilic infiltration. The lungs alveoli were distended and ruptured in advance stage (Fig. 6). In kidneys, the capillaries were congested and hemozoinic pigments were present in congested blood. Renal tubules were necrosed with the disintegration of necrotic cellular mass accompanied with focal accumulation of reactive cells (Fig. 7). These findings are some what similar to the result described by Yin et al. (2002), who studied the pathology of experimentally infected $L$. caulleryi infection in 300 chickens. This change might be due to the liberation of gametocytes from the affected cells. 


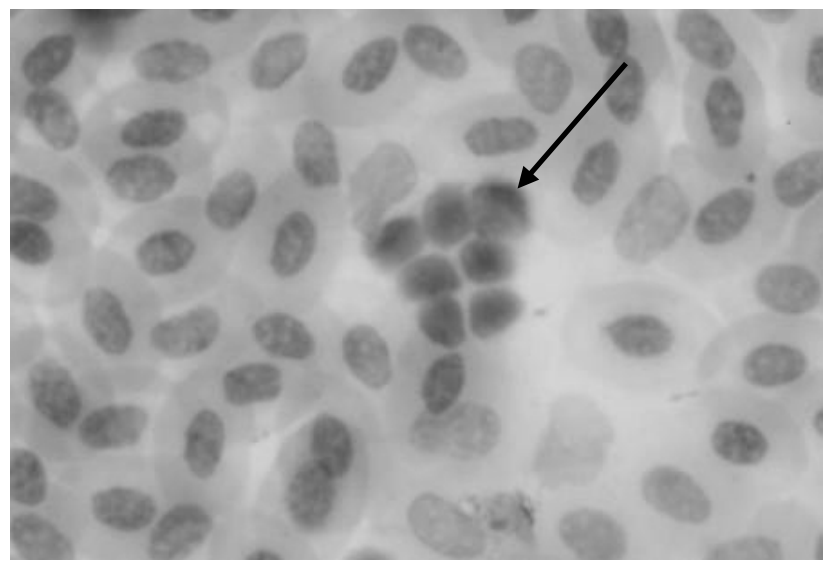

Fig. 1. Developmental stage of Leucocytozoon simondi (arrow) in lymphocyte in the blood film of duck, stained with Giemsa's stain (825X).

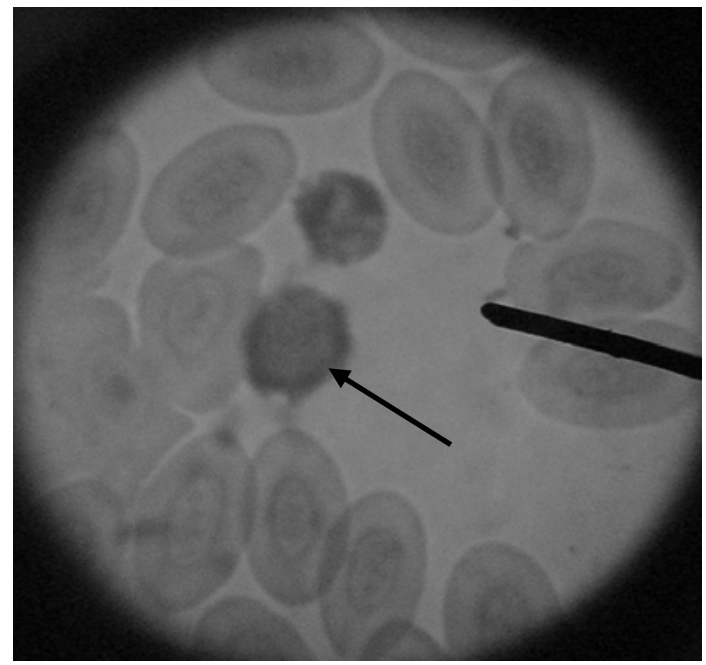

Fig. 2. Leucocytozoon caulleryi (arrow) infected lymphocyte in the blood film of chicken stained with Giemsa's stain (825X).

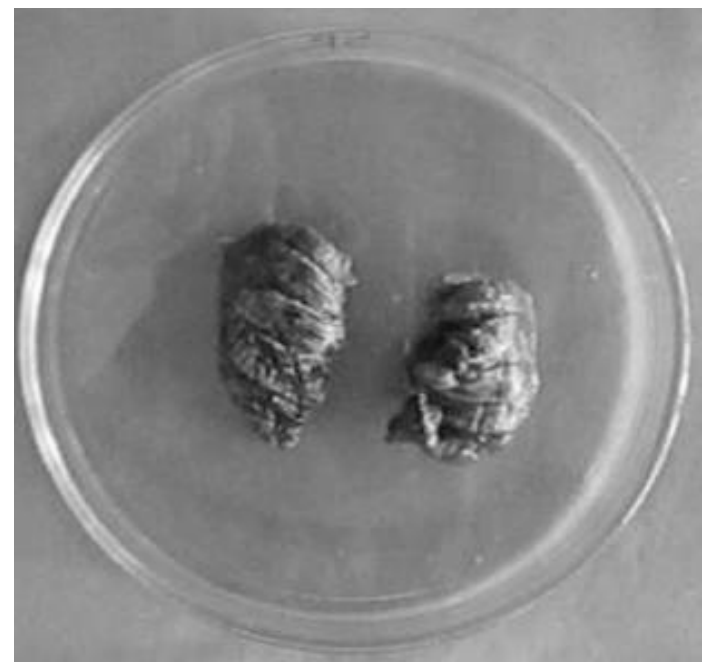

Fig. 3. Congested lungs affected with Leucocytozoon sp. in duck. 


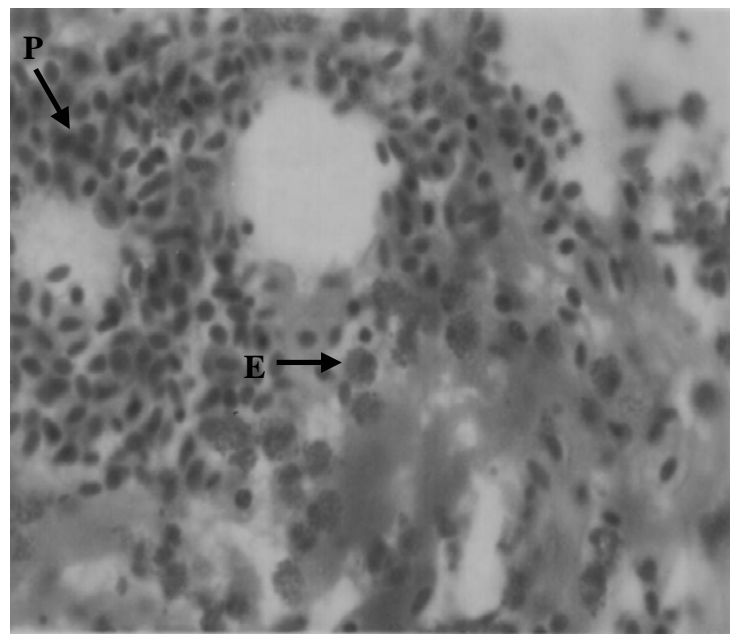

Fig. 4. Lungs infected with hemoprotozoa (P). Characterized by the infiltration of eosionophils (E). Few RBC contain duplicate nuclei seems to be the gamate of protozoa $(\mathrm{P})(825 \mathrm{X})$.

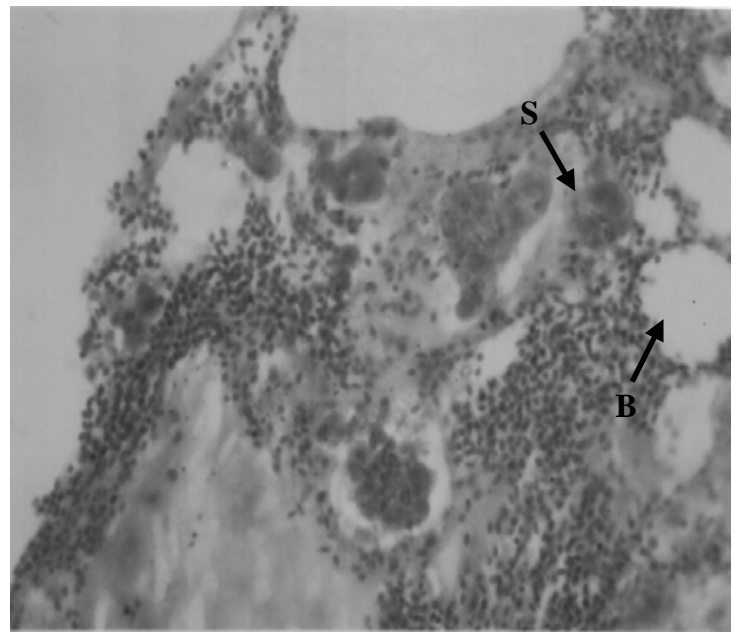

Fig. 6. Lung showing schizonts (S), neutrophilic infiltration and distended ruptured lung alveoli (B) (825X).

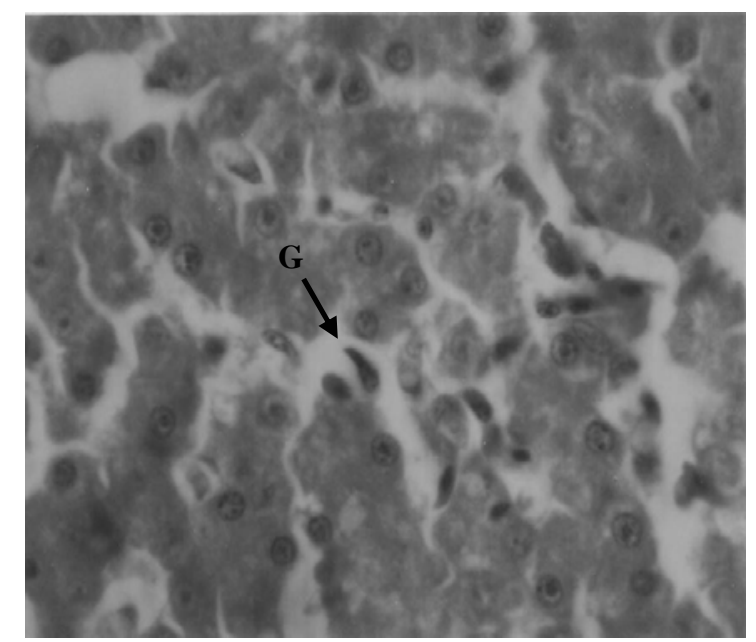

Fig. 5. Liver containing comma shaped gamate $(\mathrm{G})$ of hemoprotozoan in between the cord of hepatocytes (825X).

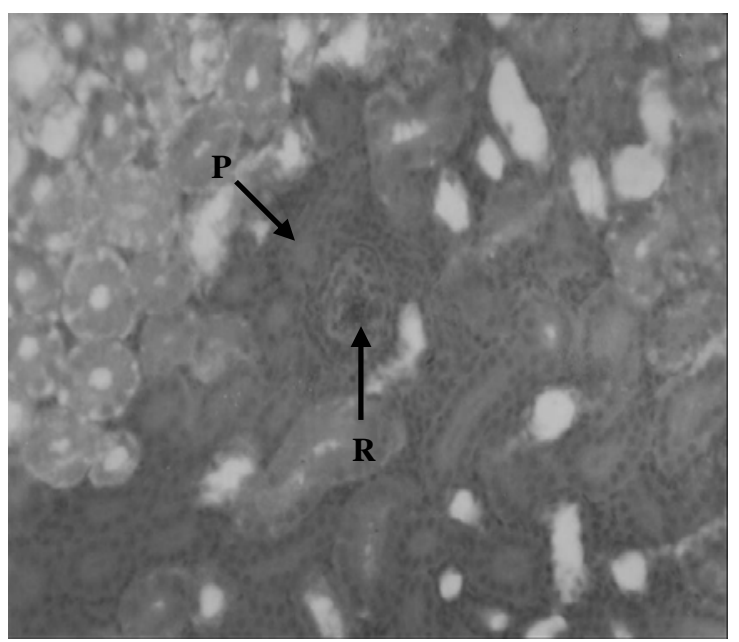

Fig. 7. Necrosis of renal tubular epithelium and blocking of the tubular lumen with proteinaeceous mass $(\mathrm{P})$ along with the infiltration of reactive cells $(\mathrm{R})$ in the affected glomeruli (825X). 


\section{REFERENCES}

1. Ackert JE and Dewhirst LW (1950). Resistance of fowls to parasitism affected by female sex hormone. Journal of Parasitology 36: 16.

2. Anon (2007). Statistical pocket book of Bangladesh. Bangladesh Bureau of Statistics (Statistics division), Ministry of Planning. Government of the People's Republic of Bangladesh.

3. Bennett GF, Smith AD, Whitman W and Cameron M (1975). Hematozoa of the Anatidae of the Atlantic Flyway. II. The Maritime Provinces of Canada. Journal of Wildlife Disease 11: 280-289.

4. Bennett GF, Stotts VD and Bateman MC (1991). Blood parasites of black ducks and other anatids from Labrador and insular Newfoundland. Canadian Journal of Zoology 69: 1405-1407.

5. Bensch SJ, Pe'rez-Tris J, Waldenstro M and Hellgren O (2004). Linkage between nuclear and mitochondrial DNA sequences in avian malaria parasites: Multiple cases of cryptic speciation. Evolution 58: 1617-1621.

6. Cable RM (1957). An Illustrated Laboratory Manual of Parasitology. $4^{\text {th }}$ edn., Burges Publishing Co., Minneapolis 15, Minnesota, USA. pp. 114-115.

7. Forrester DJ, Foster GW and Thul JE (2001). Blood parasites of the ring-necked duck (Aythya collaris) on its wintering range in Florida, U.S.A. Comparative Parasitology 68: 173-176.

8. Fowler NG (1990). How to carry out a field investigation In: Poultry Diseases, FTW Gordon (Ed.) Bailliere Tindall, London, pp. 370-400.

9. Hellgren O, Waldenstro MJ and Bensch S (2004). A new PCR assay for simultaneous studies of Leucocytozoon, Plasmodium, and Haemoproteus from avian blood. Journal of Parasitology 90: 797-802.

10. Islam MN, Huque QME, Salahuddin M and Sarker MSK (2003). Potentiality of native genotypes of ducks. Proceedings of the $3^{\text {rd }}$ International Poultry Show and Seminar. World Poultry Science Association-Bangladesh Branch. pp. 259.

11. Levine ND (1985). Veterinary Protozoology. $1^{\text {st }}$ edn., Iowa State University Press, Ames, pp. 266-282.

12. Luna LG (1968). Manual of Histologic Staining Methods of the Armed Forces Institute of Pathology. $3^{\text {rd }}$ edn., McGraw Hill Book Co., New York.

13. Ricklefs RE, Swanson BL, FalloN SM, Abrain AM, Scheuerlein A, Gray J and Latta SC (2005). Community relationships of avian malaria parasites in southern Missouri. Ecological Monographs 75: 543-559.

14. Shutler D, Ankney CD and Mullie A (1999). Effects of the blood parasite Leucocytozoon simondi on growth rates of anatid ducklings. Canadian Journal of Zoology 77: 1573-1578.

15. Soulsby EJL (1982). Helminths, Arthropods and Protozoa of Domesticated Animals. $7^{\text {th }}$ edn., Baillire Tindall. pp. 35740 .

16. Springer WT (1997). Other blood and tissue protozoa. In: Diseases of Poultry. $10^{\text {th }}$ edn., Calnek BW, Barnes HJ, Beard HJ, McDougald LR and Saif YM (eds). Iowa State University Press, USA. pp. 900-911.

17. Thul JE, Forrester DJ and Greiner EC (1980). Hematozoa of wood ducks (Aix spons) in the Atlantic flyway. Journal of Wildlife Disease 16: 383-390.

18. Todd AC and Holingsworth KP (1951). Host sex as a factor in development of Ascaridia galli. Experimental Parasitology 1: 303-304.

19. Williams NA, Calverley BK and Mahrt JL (1977). Blood parasites of mallard and pintail ducks from central Alberta and the Mackenzie Delta, Northwest Territories. Journal of Wildlife Disease 13: 226-229.

20. Yin Z, Wang K and Jia R (2002). Pathomorphological observation on experimental Leucocytozoon caulleryi. Chinese Journal of Veterinary Science 22: 597-600. 